\title{
Fungal Diversity and Evaluation of Ochratoxin A Content of Coffee from Three Cameroonian Regions
}

\author{
N. D. Nganou $\mathbb{D}^{1},{ }^{1}$ E. S. Tchinda, ${ }^{1}$ T. N. Noumo, ${ }^{2}$ H. T. Mouafo, ${ }^{3}$ A. T. Sokamte, ${ }^{4}$ \\ and L. N. Tatsadjieu $\mathbb{D}^{1}$ \\ ${ }^{1}$ Bioprecess Laboratory, Department of Food Technology and Quality Control, University Institute of Technology, \\ University of Ngaoundéré, P.O. Box 455, Ngaoundéré, Cameroon \\ ${ }^{2}$ Department of Food Science and Technology, College of Technology, University of Bamenda, P.O. Box 39, Bambili, Cameroon \\ ${ }^{3}$ Food Analysis and Quality Control Laboratory, Centre for Food and Nutrition Research, \\ Institute of Medical Research and Medicinal Plants Studies, P.O. Box 13033, Yaoundé, Cameroon \\ ${ }^{4}$ Food Microbiology and Biotechnology Laboratory, Department of Food Science and Nutrition, \\ National Advanced School of Agro-Industrial Sciences, University of Ngaoundéré, P.O. Box 455, Ngaoundéré, Cameroon
}

Correspondence should be addressed to N. D. Nganou; nganou_nadege@yahoo.fr

Received 7 May 2020; Revised 20 September 2020; Accepted 26 September 2020; Published 12 October 2020

Academic Editor: Daniel Cozzolino

Copyright $\odot 2020$ N. D. Nganou et al. This is an open access article distributed under the Creative Commons Attribution License, which permits unrestricted use, distribution, and reproduction in any medium, provided the original work is properly cited.

The present study had the objective to assess the ochratoxin A content of coffee through chromatographic analysis and design a method using PCR-DGGE to analyze at the same moment the totality of fungal flora present in the coffee samples in order to determine their geographic origin. 96 samples of coffee were collected from the west region (Bafoussam and Dschang), centre region (Bafia), and east region (Batouri) of Cameroon during two years (2017 and 2018). Two treatments (dry and wet routes) were evaluated at three different steps of coffee processing (parchment coffee, green coffee, and husk coffee). The characterization of the fungal profile was done with PCR-DGGE and sequencing. The levels of OTA were assessed using HPLC analysis. The results indicated that the toxinogenic mycoflora associated with coffee beans was mainly Aspergillus niger, A. carbonarius, and A. ochraceus. PCR-DGGE data revealed that each sampling site is characterized by a specific fungal profile. Despite the influence of the treatment on the fungal population of coffee, bands common to samples coming from the same site were observed. These bands could therefore constitute potential biological markers to trace back to the origin of coffee. OTA was detected in most of the coffee samples analyzed and only few samples contented OTA at levels higher than the maximum tolerable limit for food intended for human consumption. The OTA content of coffee was significantly influenced by the sampling step and the sampling period.

\section{Introduction}

Coffee is one of the raw materials mostly exchanged through the world, which occupies the first place in terms of volume and values in the culture of agricultural rent products [1]. Brazil is the largest producer followed by Vietnam and Colombia. Cameroon is among the African countries having their own part on that coffee market [2]. Even if the coffee branch is very flourishing, some impediments can be noticed to its development such as a fall in world prices [1], the fall of incomes per producer, dwindling of arable lands, weak production yields, and difficulties of farmers to appropriate modern production techniques [1]. Moreover, coffee has an intrinsic potential quality which strongly depends on the variety of trees planted, the culture conditions and seasons, the geographic origin, and the agronomic know-how of farmers. But that potential can be valorized or degraded in opposite during the postharvest operations $[3,4]$.

The processing technology of coffee beans to green coffee is too long and requires a primary process of handling. In association to this, there is treatment through dry and/or wet routes as well as storage and transportation $[5,6]$. These postharvest treatments insured by the producers and for which fermentation is the most important step, participate 
and generally print the organoleptic and merchantable qualities of products intended for the processing [7]. Hence, a worse postharvest treatment of coffee beans can lead to the apparition of some spoilage traits on the products (mouldy, decay, and germination) as the result of microorganisms' activities (bacteria, moulds, etc.) [1,8]. These will have an impact on the merchantable quality of the product leading to considerable losses, mostly economic ones [9].

Furthermore, in the international trade of coffee, one of the indicators of the safety security required for the product is the absence of OTA. OTA is a toxic secondary metabolite derived from some moulds, especially those that belonged to the Aspergillus genus in tropical areas and Penicillium genus in tempered areas $[10,11]$. Even if several studies demonstrated the relationship between the frequency and the toxinogen potential of moulds in relation to the postharvest treatments of coffee, there is still a lack of information regarding the mechanism of coffee contamination by mycotoxin-producing strains of moulds [12]. OTA production can occur during the whole period of the postharvest process, the storage, and the transportation of coffee [13]. The presence of OTA in coffee is responsible for its main rejects on world markets. In the European Union which is the main destination of coffee coming from Cameroon, OTA is together with aflatoxin $\mathrm{B}_{1}\left(\mathrm{AFB}_{1}\right)$, the most monitored and controlled mycotoxin. In fact, the absence of OTA is required because that metabolite is very harmful for humans and animals as it possesses nephrotoxic, immunotoxic, teratogenic, and carcinogenic effects [14-18]. The serious hazards that OTA generated on the consumers' health have led the safety services of the European Union to establish norms that define the maximal tolerable limits of OTA in many agricultural commodities (cereals, grape, coffee, etc.). In the regulation no. 1881/2006 of the European Commission, the maximal tolerable limit of OTA is $5 \mu \mathrm{g} / \mathrm{kg}$ of coffee beans [19]. According to the scientific comity of human food of the FAO and WHO [20], it is prudent to reduce the OTA exposition below $8 \mu \mathrm{g} / \mathrm{kg}$ of body weight per day. It therefore needs to abide by the current regulation. Hence, careful consideration should be given to OTA. The objective of this study is to assess the OTA content of coffee from three Cameroonian regions and identify the fungal flora associated with its contamination.

\section{Materials and Methods}

2.1. Sampling. The sampling of coffee was performed during the month of May of the years 2017 and 2018 in three regions of Cameroon (west, centre, and east). These regions were chosen based on their rate of production. The half production of Cameroonian coffee comes from these regions. Moreover, the important distance between these agroecological zones was also used as selection criteria. In the west region, sampling was done at Bafoussam $\left(5^{\circ} 28^{\prime} 0\right.$, $\left.72^{\prime \prime} \mathrm{N}-10^{\circ} 25^{\prime} 0,48^{\prime \prime} \mathrm{E}\right)$ and Dschang $\left(5^{\circ} 27^{\prime \prime} \mathrm{N}-10^{\circ} 04^{\prime} 00^{\prime \prime} \mathrm{E}\right)$, at Bafia $\left(4^{\circ} 45^{\prime} 00^{\prime \prime} \mathrm{N}-11^{\circ} 13^{\prime} 00^{\prime \prime} \mathrm{E}\right)$ in the centre region, and at Batouri $\left(4^{\circ} 26^{\prime} 00^{\prime \prime} \mathrm{N}-14^{\circ} 22^{\prime} 00^{\prime \prime} \mathrm{E}\right)$ in the east region. Bafoussam and Dschang are very close but represent the sites where $75 \%$ of the arabica coffee is produced in Cameroon.
48 samples of $500 \mathrm{~g}$ each were collected in coffee bags of $50 \mathrm{~kg}$ ( $100 \mathrm{~g}$ at five different points of the bag) each year leading to a total of 96 samples for the two years. The description of the sampling process is presented in Table 1.

Three producers in each region were selected during sampling and labeled sites numbers 1, 2, and 3, respectively. The sample collection was done at different steps of the coffee processing as shown in Figure 1. These steps were dried cherries (I), husk coffee (II), and green coffee beans (III). They were chosen because only coffee is sold in dry form and previous studies reported that the OTA contamination problems of coffee are linked to the dry cherries, the dry husk of coffee, and the dry green coffee beans $[9,13]$. Two types of postharvest treatments were applied to the coffee: the treatment through wet route for arabica coffee (well ripped cherries) and the treatment through dry route for robusta and arabica coffee (immature or damaged cherries). Figure 1 resumes the different processes of coffee treatment as well as the different steps of sample collection.

\subsection{Direct Analyses of Microbial Communities by Molecular} Biology Technics. The fungal flora of the different samples of coffee was screened through their direct analysis by PCR-DGGE. This method was chosen because, according to the literature, it is a rapid method for analyses of the microbial communities on food [21]. The efficiency (number of species identified) and the rapidity of the PCR-DGGE method were reported by Laforgue et al. [22] and Nganou et al. [23] while assessing the fungal profile of coffee.

2.2.1. Extraction of DNA from Coffee Beans. In aseptic conditions, $8 \mathrm{~g}$ of coffee bean samples were introduced into sterile tubes of $50 \mathrm{~mL}$ and $10 \mathrm{~mL}$ of sterile peptone water were added. The tubes containing the mixture were placed for $1 \mathrm{~h}$ on a rotating wheel. The supernatants $(2 \mathrm{~mL})$ were taken and transferred into Eppendorf tubes followed by the addition of $0.3 \mathrm{~g}$ of glass beads. The protocol of El Sheikha [24] was used for DNA extraction. The purity of DNA was checked by electrophoresis and the DNA was loaded into a gel made of agarose $0.8 \%$ in $1 x$ TAE buffer $(40 \mathrm{mM}$ Tris- $\mathrm{HCl}$, $\mathrm{pH} 7.4,20 \mathrm{mM}$ sodium acetate, and $1.0 \mathrm{mM} \mathrm{Na}$-EDTA), which contained a molecular weight ladder. The migration was run at $100 \mathrm{~V}$ for $30 \mathrm{~min}$ and a gel red solution $(50 \mathrm{mg} /$ $\mathrm{mL}$, Biotium) was used to color the gels. The colored gels were observed on a UV transilluminator, photographed using a black, and white CCD camera (Scion Company) and data acquisition was performed using Gel Smart 7.3 system software (Clara Vision).

2.2.2. PCR Amplification. Universal eukaryotic primer for PCR was successfully applied to amplify and identify several species of fungi in a unique PCR step. In previous reported studies, a fragment of a specific region of the $28 \mathrm{~S}$ rDNA, called the D2 region, was amplified while using the following universal eukaryotic primers: forward, U1f GC (5'-CGC 
TABLE 1: Summary of the sampling procedure in the three Cameroonian regions and the number of samples collected.

\begin{tabular}{|c|c|c|c|c|c|c|c|c|c|}
\hline \multirow{2}{*}{ Sampling period } & & \multicolumn{8}{|c|}{ Sampling sites } \\
\hline & & \multicolumn{3}{|c|}{ Bafoussam } & \multicolumn{3}{|c|}{ Dschang } & \multirow{3}{*}{$\begin{array}{c}\text { Bafia } \\
\text { DP } \\
\text { R }\end{array}$} & \multirow{3}{*}{$\begin{array}{c}\text { Batour } \\
\mathrm{DP} \\
\mathrm{R}\end{array}$} \\
\hline \multirow{2}{*}{\multicolumn{2}{|c|}{$\begin{array}{l}\text { Processing technique } \\
\text { Variety of coffee }\end{array}$}} & \multicolumn{2}{|c|}{$\mathrm{DP}$} & \multirow{2}{*}{$\begin{array}{c}\text { WP } \\
\text { A }\end{array}$} & \multicolumn{2}{|c|}{$\mathrm{DP}$} & \multirow{2}{*}{$\begin{array}{c}\text { WP } \\
\text { A }\end{array}$} & & \\
\hline & & $\mathrm{R}$ & $\mathrm{A}$ & & $\mathrm{R}$ & A & & & \\
\hline \multirow{2}{*}{ Year of collection } & 2017 & 6 & 6 & 6 & 6 & 6 & 6 & 6 & 6 \\
\hline & 2018 & 6 & 6 & 6 & 6 & 6 & 6 & 6 & 6 \\
\hline Total number of sam & & & & & & 96 & & & \\
\hline
\end{tabular}

DP: dry process; WP: wet process; R: robusta; A: arabica.

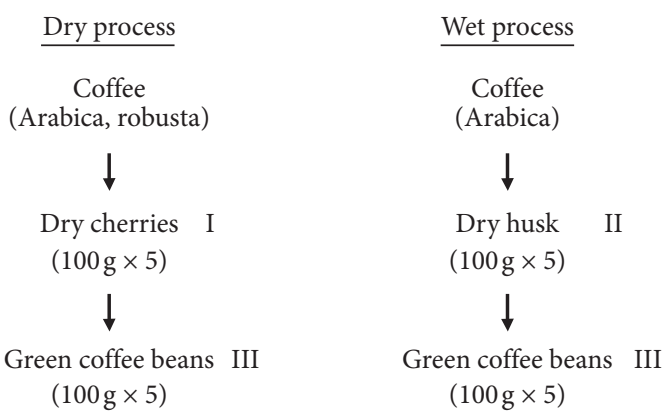

FIGURE 1: Short coffee processing steps in Cameroon. I, II, and III: sampling steps.

CCG CCG CGC GCG GCG GGC GGG GCG GGG GTG AAA TTG TTG AAA GGG AA-3 $\left.{ }^{\prime}\right)$ and reverse, U2r ( $5^{\prime}$ GAC TCC TTG GTC CGT GTT-3') [24-27]. In the present study, after the addition a $30 \mathrm{bp} \mathrm{GC}$ clamp (Sigma) on the forward universal eukaryotic primer procured from Sigma, PCR was carried out in a final volume of $50 \mu \mathrm{L}$ containing $1.5 \mathrm{mM}$ of $\mathrm{MgCl}_{2}, 5 \mu \mathrm{L}$ of $\mathrm{MgCl}_{2}$-free 10x Taq reaction buffer (Promega), all the deoxyribonucleotide triphosphate (dNTPs) at $200 \mu \mathrm{M}, 0.2 \mu \mathrm{M}$ of each primer, $2 \mu \mathrm{L}$ of extracted DNA $(\approx 30 \mathrm{ng}$ ), and 1.25 Units of Taq DNA polymerase (Promega). The amplification conditions were an initial denaturation for 3 min at $94^{\circ} \mathrm{C}, 30$ cycles of heating at $94^{\circ} \mathrm{C}$ for $45 \mathrm{sec}$, cooling at $50^{\circ} \mathrm{C}$ for $50 \mathrm{sec}$, heating at $72^{\circ} \mathrm{C}$ for $90 \mathrm{sec}$, and a final extension of $5 \mathrm{~min}$ at $72^{\circ} \mathrm{C}$. To verify the PCR products, an electrophoresis was performed by loading $5 \mu \mathrm{L}$ of these products on $2 \%$ TAE agarose gels with a $100 \mathrm{pb}$ molecular weight ladder. Gels staining and photography were carried out as mentioned above.

2.2.3. DGGE Analysis. A Bio-Rad D code universal mutation detection system (Bio-Rad, USA) was used to analyze the PCR products by DGGE. This analytical procedure was firstly described by El Sheikha [24]. Briefly, samples with approximately equal quantities of PCR amplicons were loaded into gels. These gels were made of $8 \% \mathrm{w} / \mathrm{v}$ polyacrylamide (acrylamide: $\mathrm{N}, \mathrm{N}^{\prime}$-methylene bisacrylamide, $37: 1)$ procured from Promega, in a $1 \mathrm{x}$ TAE buffer $(1.0 \mathrm{mM}$ $\mathrm{Na}_{2}$-EDTA, $20 \mathrm{mM}$ sodium acetate, and $40 \mathrm{mM}$ Tris- $\mathrm{HCl}$ at $\mathrm{pH}$ 7.4). $60^{\circ} \mathrm{C}$ was set as the temperature to perform the different electrophoresis experiments and a denaturing gradient in the range of $40-70 \%(100 \%$ corresponded to $7 \mathrm{M}$ urea and $40 \% \mathrm{v} / \mathrm{v}$ of formamide; Promega) was used. Electrophoresis was run at for $10 \mathrm{~min}$ at $20 \mathrm{~V}$ and then for
$16 \mathrm{~h}$ at $80 \mathrm{~V}$, and a gel red solution $(50 \mathrm{mg} / \mathrm{mL}$; Biotium) was used to stain the gels. Gels observations were performed on UV transilluminator; photographs were taken using a camera and data acquisition done with Gel Smart 7.3 system.

2.2.4. Purification and Identification of DGGE Bands. The bands detected on the DGGE gel were excised with a sterile scalpel. $100 \mu \mathrm{L}$ of TE buffer was used to elute overnight and at $4^{\circ} \mathrm{C}$, the DNA of each excised band. $100 \mu \mathrm{L}$ of each eluate was purified and sequenced at GATC Biotech (Germany) as mentioned above. The only difference was the U1 primer used which did not contain GC clamp. Sequence Scanner Software V1.0 was used to edit the raw sequence data and the edited sequences were compared to those described in the GenBank database through the Basic Local Alignment search Tool (http://www.ncbi.nlm.nih.gov/ BLAST/) [28] and the Ribosomal Database Project (http:// www.rdp.cme.msu.edu/index.jsp). Sequences having an identity percentage $\geq 97 \%$ were considered as belonging to the same species $[29,30]$.

2.2.5. Analysis of DGGE Gels. An Image Quant TL software V.2003 (Amersham Biosciences, USA) was used in this study to analyze the DGGE gels obtained. Two fungal reference patterns (A. niger and A. carbonarius) were used as control in order to standardize the band patterns appearing in each lane. The relative positions of the different bands were compared with standard patterns. According to cited reports, the banding pattern generated in DGGE analysis is considered as an image of the whole major fungal populations [31, 32]. Hence, each individual band refers to a unique "phytotype" or "sequence type," This was also 
confirmed by Kowalchuk et al. [33] in their studies. They showed that identical sequences generally present comigrating bands in DGGE analysis.

The presence or absence of comigrating bands, independently of their intensity, was used to manually score the DGGE fingerprinting. The following formula was used to calculate the dice similarity coefficient which was used later to quantify the pair wise community similarities [34]:

$$
S_{D}=\frac{2 N_{c}}{N_{a}+N_{b}},
$$

with $N_{a}$ which represented the number of bands detected in sample $\mathrm{A}, N_{b}$ the number of bands in sample $\mathrm{B}$, and $N_{c}$ the number of bands common to the both samples.

An interval ranging from 0 (completely dissimilar) to 100 (perfect similarity) was used to express the similarity index. In order to visualize the association between the fungal communities of the coffee and the sampling sites (cities), a factorial analysis of correspondence (FAC) was performed using the software Statistica version 7 (StatSoft, USA).

\subsection{Determination of OTA Contents of the Coffee Beans} Samples. Frozen samples of coffee beans $\left(-80^{\circ} \mathrm{C}\right)$ were ground and sieved $(0.5 \mathrm{~mm})$ and their OTA contents were assessed following the method described by Nakajima et al. [35]. Briefly, sample $(10 \mathrm{~g})$ was introduced into a phial and $100 \mathrm{~mL}$ of the extraction solution (methanol and solution of sodium bicarbonate $3 \%(50: 50, \mathrm{v} / \mathrm{v})$. After $30 \mathrm{~min}$ of extraction, the mixture was centrifuged. The collected supernatant was diluted $(10: 30, \mathrm{v} / \mathrm{v})$ with a solution of phosphate buffered saline $(\mathrm{pH}$ 7.3) and filtered using an immunoaffinity column (Ocharaprep R, Rhône Diagnostics, Scotland). HPLC grade methanol $(3 \mathrm{~mL})$ was used to elute OTA. After flash evaporation under nitrogen stream $\left(70^{\circ} \mathrm{C}\right)$, the residue was dissolved in $1 \mathrm{~mL}$ of HPLC mobile phase (water/acetonitrile/glacial acetic acid, 51:48:1) and then quantified using a Shimadzu HPLC (Shimadzu LC10ADVP, Japan) equipped with a fluorescence detector. Elution was carried out at a flow rate of $1 \mathrm{~mL} / \mathrm{min}$. Peak corresponding to OTA was detected at a retention time between 12.3 and $12.5 \mathrm{~min}$ and absorption at $333 \mathrm{~nm}$ excitation and $460 \mathrm{~nm}$ emission. Calibration curve was drawn with solutions of OTA at different concentrations ( 0 to $50 \mu \mathrm{g} / \mathrm{kg}$ ) prepared from an OTA standard solution (1000 ng/mL; ref P 226 R, Biopharm Rhône Ltd, Scotland). The precision, the limit quantification, and the limit of detection of the instrument were $8 \%, 0.15 \mu \mathrm{g} / \mathrm{kg}$, and $075 \mu \mathrm{g} /$ $\mathrm{kg}$, respectively. The recovery was $85 \%$.

2.4. Statistical Analyses. The OTA data obtained were submitted to analysis of variance (ANOVA) and multiple range tests using the statistical software XLSTAT 2014 (Addinsof, Inc., New York, USA). Correlation between the fungal diversity, the geographic origin, the coffee cultivar, and the processing method was performed using a comparative $Z$-test.

\section{Results and Discussion}

3.1. DGGE Analysis of the Representative Fungal Flora of Coffee Samples. The DNA electrophoretic profile of coffee samples collected from the different sites (Bafoussam, Dschang, Batouri, and Bafia) is presented in Figure 2. On that gel (Figure 2), each band represents a mould and each vertical line represents a sample. The first and last wells, respectively, filled with $A$. niger and $A$. carbonarius (marker strains), were used as controls. It can be seen (Figure 2) that the DGGE profile of each site was identical to each other (e.g., $\mathrm{A} 1, \mathrm{~B} 1, \mathrm{~N} 1$, and $\mathrm{N} 2$ ) but differed from one site to another.

From the DNA electrophoretic profile (Figure 2), 19 bands were removed from the gel, purified, and submitted to sequencing in order to identify the corresponding mould strains. The results of sequencing are noticed in Table 2 . Thirteen different species of moulds were identified (Table 2). The presence of OTA-producing strains like A. niger, A. ochraceus, and A. carbonarius among the identified strains, suggested the possible contamination of coffee samples with OTA. This result is in accordance with the reports of Nganou et al. [23]. These authors demonstrated in their studies the production of OTA by mould strains isolated from coffee and identified as A. niger, A. carbonarius, and A. ochraceus [23].

The distribution of strains according to the treatment applied to coffee showed that treatment through the wet route (Bafoussam and Dschang) leads to obtain a more important and abundant fungal diversity than that with dry route (Bafia and Batouri). Independent of the year of sampling and the treatment method applied to coffee, the fungal flora did not vary. However, when the sampling step of the two treatment methods is taking in consideration, a substantial reduction of the rate of the fungal diversity was noticed from Step I (O1 and $\mathrm{O} 2)$ to Step III (C1 and D1) in the treatment through the dry route and from Step II (A1 and B1) to Step III (P1 and P2) in the treatment through the wet route. The reduction of the fungal diversity observed in Step III could be justified by the husking process which was applied to coffee in the treatment through the dry route or the washing process which was applied to coffee in the treatment through the wet route. The influence of husking and washing processes in the reduction of fungal diversity of coffee was also noticed by Duris et al. [13]. On the other hand, the great diversity of fungal flora observed in Step I in the treatment through the dry route or in Step II in the treatment through the wet route could result from the fact that, during the drying process, coffee beans are directly in contact with air and soil which could be a possible source of contamination. Moreover, climatic variation and the aeration conditions of the storage room (made of the grid disposed along the wall not far from the roof) rendered impossible the monitoring of the storage room temperature.

3.2. Variations in the Structure of Fungal Communities according to Geographical Origin of Cameroonian Coffee. On the gel presented in Figure 3, it can be observed that the extracted DNA of the control strains showed intense and unique bands located at the expected position. This confirms 


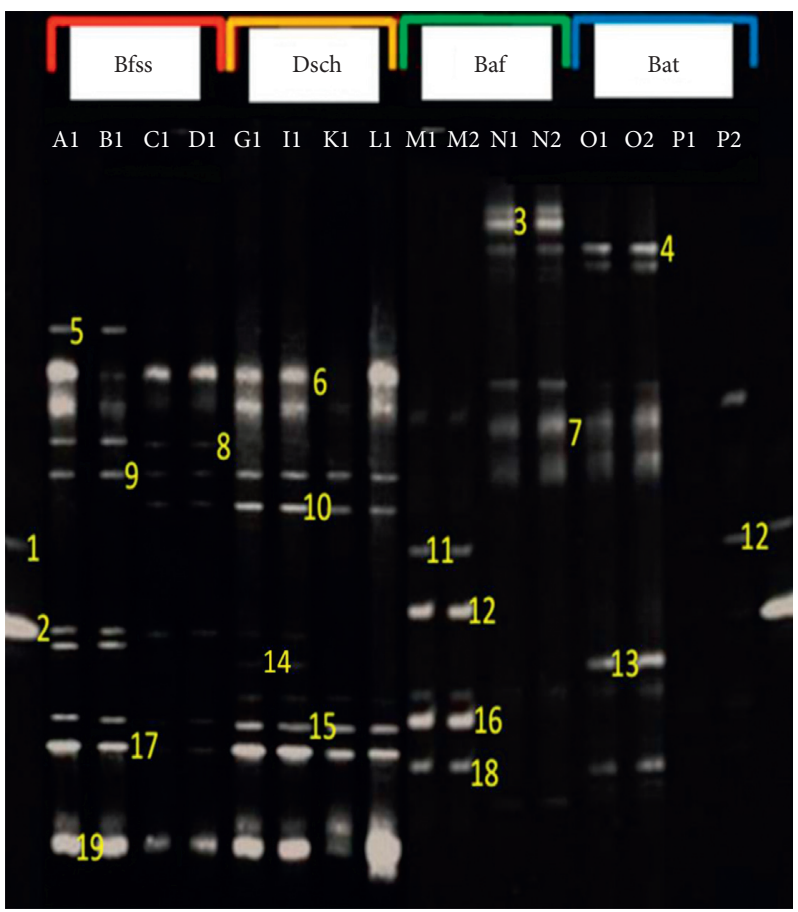

FIGURE 2: DGGE profiles of PCR amplicons of the domain D1 of 28S rDNA that represent the fungi biodiversity in of coffee. Markers (1, 2); Bfss: Bafoussam; Dsch: Dschang; Baf: Bafia; Bat: Batouri. The position of bands is indicated by numbers that correspond to species of fungi.

TABLE 2: Identification of fungal DNA bands excised from DGGE gels.

\begin{tabular}{|c|c|c|c|c|}
\hline Number & Family/genus/species & Percent identity (\%) & Query cover (\%) & References \\
\hline 1 & Aspergillus Niger & 99 & 100 & CET 2091 \\
\hline 2 & Aspergillus carbonarius & 100 & 100 & AJ280011 \\
\hline 3 & Mucor racemosus & 95 & 100 & AY213659 \\
\hline 4 & Mucor sp. & 90 & 100 & $*$ \\
\hline 5 & NI & & & $*$ \\
\hline 6 & NI & & & * \\
\hline 7 & Wallemia sebi & 91 & 100 & JF497133 \\
\hline 8 & NI & & & $*$ \\
\hline 9 & Wallemia muriae & 90 & 100 & MH875564 \\
\hline 10 & Acremonium murorum & 95 & 100 & FN706554 \\
\hline 11 & Aspergillus Niger & 99 & 100 & AJ280006 \\
\hline 12 & Aspergillus ochraceus & 100 & 100 & AY609206 \\
\hline 13 & Aspergillus fumigatus & 100 & 100 & AY214446 \\
\hline 14 & Fusarium sp. & 99 & 100 & $*$ \\
\hline 15 & Cladosporium musae & 95 & 100 & AY 186200 \\
\hline 16 & Cladosporium musae & 91 & 100 & AY186202 \\
\hline 17 & Aspergillus nomius & 100 & 100 & AY017542 \\
\hline 18 & Penicillium roqueforti & 90 & 100 & AJ005677 \\
\hline 19 & Aspergillus sp. & 99 & 100 & * \\
\hline
\end{tabular}

NI: not identified. ${ }^{*}$ More access numbers are offered.

that successful completion of the DGGE. For each deposit point, 6 to 11 intense and distinct bands were observed (Figure 3). A deep observation of each site (Figure 3) showed that the coffee samples coming from the same city displayed the same DGGE profile. However, the DGGE profile is different from one city to another as the number and position of bands vary with the cities (Figure 3 ). These differences observed in the DGGE profiles according to the cities could be attributed to the environment of the regions where these cities are located. The type of treatment applied to coffee could also influence its fungal communities. Bands corresponding to a group of moulds common to the different sites (cities), were noticed with the different samples of coffee analyzed independent of the sampling city or the variety of coffee (Figure 3 ). These bands could be indicative of moulds which are common to all samples of coffee.

In order to compare the mould communities of the coffee sampled in four different cities, factorial analysis of 


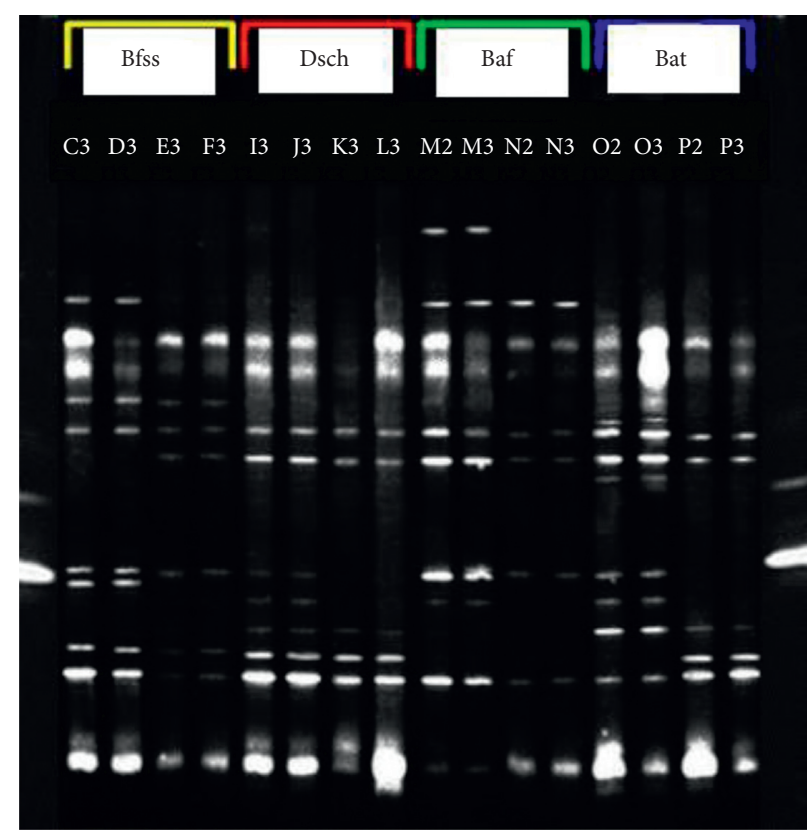

FIGURE 3: DGGE profiles of DNA extracted from moulds of coffee samples collected in four Cameroonian cities: Bafoussam, Dschang, Bafia, and Batouri. Bfss: Bafoussam; Dsch: Dschang; Baf: Bafia; Bat: Batouri.

correspondence was performed. Despite the limited number of bands observed that factorial analysis of correspondence was the best statistical analysis which clearly brought out the differences and similarities between the mould communities of the different cities. The two-variance design observed in Figure 4 describes the $86.9 \%$ of data variations with a good discrimination for the 4 different groups originated from 4 different cities. In each city, it can be observed that two bands appeared: I3 and J3 (Dschang), C3 and D3 (Bafoussam), M2 and M3 (Bafia), and O2 and O3 (Batouri). These two bands correspond to two species of moulds which are specific to each site, thus suggesting that these two mould species can be used as potential markers for these cities. Similar observations were reported by El Sheikha and Nganou [8] in their studies. These authors highlighted that the moulds DNA can be used as potential markers to insure the determination of the geographical origin of coffee.

\section{OTA Quantification in Coffee}

Table 3 resumes the OTA contents of the different coffee samples in relation to the sampling site, the sampling year, the treatment applied to coffee, the type of coffee, and the different sampling steps of coffee processing. OTA was detected in all samples coming from Batouri and Bafia, while for those coming from Bafoussam and Dschang, the OTA level of some samples was below the detection limit (Table 3). The highest OTA content obtained in this study $(12.70 \mu \mathrm{g} / \mathrm{kg})$ was noticed in the city of Batouri (Table 3). According to the European Commission regulation no. 1881/2006, the level of OTA in coffee intended for human consumption should not exceed $5 \mu \mathrm{g} / \mathrm{kg}$ of coffee beans [19]. In this study, the OTA content of samples collected during the year 2018 was below that value
$(5 \mu \mathrm{g} / \mathrm{kg})$, while few samples collected during the year 2017 showed an OTA content higher than the norm.

In order to assess the effect of the sampling year, the sampling site, the treatment applied to coffee, the type of coffee, and the different sampling steps of coffee processing on the level of OTA in the samples of coffee, analysis of variance associated with the multiple range test was performed. Results gathered from the analysis of variance revealed that only the sampling step $(p=0.0001)$ and the sampling year $(p=0.035)$ had significantly influenced the OTA content of coffee samples as their $p$ values lower than 0.05. Castellanos-Onorio et al. [36] also showed in their studies that these two parameters significantly influenced the OTA content of coffee.

Mean values of OTA content observed in the years 2017 and 2018 were calculated and compared using the multiple range test (Table 3 ). In general, it can be observed that the average OTA content of coffee from Bafoussam, Dschang, Batouri, and Bafia has significantly $(p<0.05)$ decreased from the year 2017 to the year 2018. This decrease could be due to the fact that environmental conditions as well as storage conditions are not mastered by the producers. The variation of environmental and storage conditions as factors which significantly contributed to increase the level of OTA in coffee was reported by El Sheikha and Nganou [8].

Regarding the sampling cities (sites), mean OTA contents per city were also calculated and compared at a statistical significance of $p<0.05$ using the multiple range test. It can be observed from Table 3 that, in 2017, the sample of Robusta coffee collected in Step I of the processing process and originating from Batouri has the highest OTA content $(12.7 \mu \mathrm{g} / \mathrm{kg})$ compared to that of all other coffee samples. 


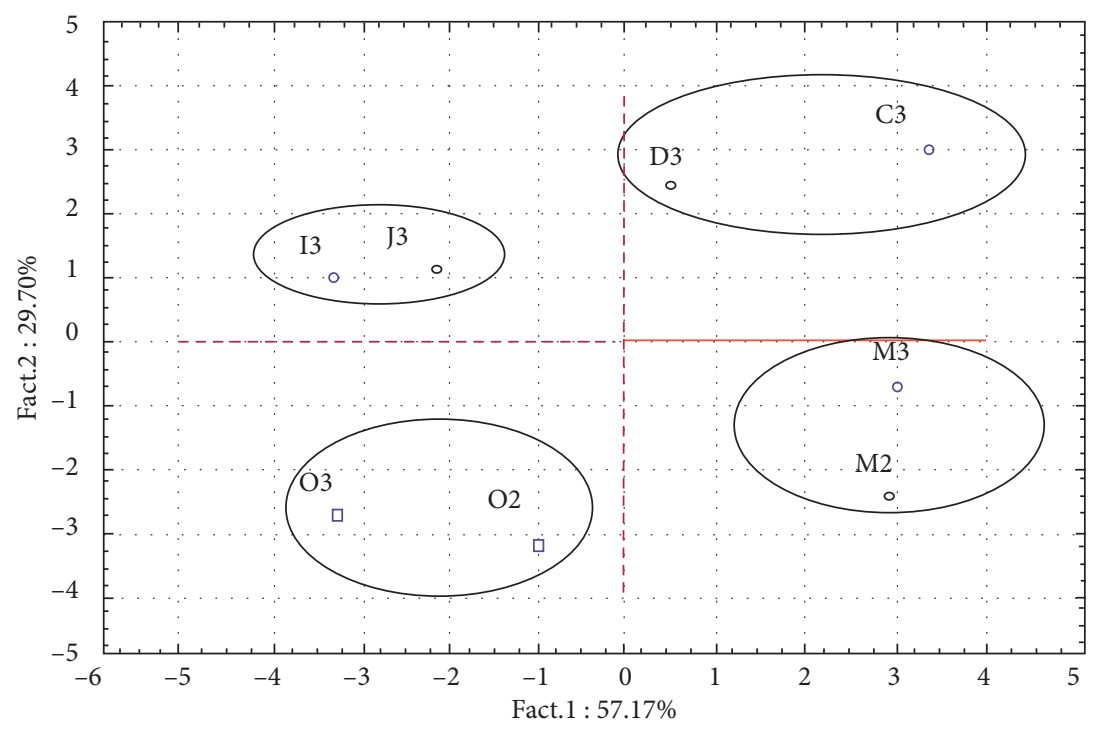

Figure 4: Factorial analysis of DGGE profile of green and husk coffees coming from four Cameroonian cities. Dschang (I3, J3); Bafoussam (D3, C3); Bafia (M2, M3); Batouri (O2, O3).

TABLE 3: OTA contents of the different samples of coffee analyzed.

\begin{tabular}{|c|c|c|c|c|c|c|}
\hline \multirow[t]{2}{*}{ Site } & \multirow[t]{2}{*}{ Processing technique } & \multirow[t]{2}{*}{ Type of coffee } & \multirow[t]{2}{*}{ Processing step } & \multirow[t]{2}{*}{ Number of samples analyzed/year } & \multicolumn{2}{|c|}{$\begin{array}{c}\text { Average OTA content } \\
(\mu \mathrm{g} / \mathrm{kg})\end{array}$} \\
\hline & & & & & Year 2017 & Year 2018 \\
\hline \multirow{6}{*}{ Bafoussam } & \multirow{4}{*}{$\mathrm{DP}$} & \multirow{2}{*}{ A } & I & 3 & 4.6 & 3.1 \\
\hline & & & III & 3 & 0.1 & $\mathrm{n}, \mathrm{d}$. \\
\hline & & \multirow{2}{*}{$\mathrm{R}$} & $\mathrm{I}$ & 3 & 8.8 & 1.8 \\
\hline & & & III & 3 & 0.6 & n.d. \\
\hline & \multirow{2}{*}{ WP } & \multirow{2}{*}{ A } & II & 3 & 0.7 & 1.3 \\
\hline & & & III & 3 & n.d. & n.d. \\
\hline \multirow{6}{*}{ Dschang } & \multirow{4}{*}{$\mathrm{DP}$} & \multirow{2}{*}{ A } & $\mathrm{I}$ & 3 & 4.1 & 0.6 \\
\hline & & & III & 3 & n.d. & n.d. \\
\hline & & & I & 3 & 7.3 & 4.8 \\
\hline & & $\mathrm{R}$ & III & 3 & 0.1 & 0.8 \\
\hline & \multirow{2}{*}{ WP } & \multirow{2}{*}{ A } & II & 3 & 1.6 & 0.8 \\
\hline & & & III & 3 & n.d. & 0.3 \\
\hline \multirow{2}{*}{ Bafia } & \multirow{2}{*}{$\mathrm{DP}$} & \multirow{2}{*}{$\mathrm{R}$} & I & 3 & 7.9 & 4.7 \\
\hline & & & III & 3 & 0.7 & 0.3 \\
\hline \multirow{2}{*}{ Batouri } & \multirow{2}{*}{$\mathrm{DP}$} & \multirow{2}{*}{$\mathrm{R}$} & I & 3 & 12.7 & 3.3 \\
\hline & & & III & 3 & 0.7 & 0.5 \\
\hline
\end{tabular}

DP: dry process; WP: wet process; A: arabica; R: robusta; I: dry cherries; II: dry parchment; III: green coffee beans; n.d.: not determined.

This level was significantly reduced in the coffee bean collected in Step III of the processing process $(0.7 \mu \mathrm{g} / \mathrm{kg})$. However, in 2018, the highest OTA levels were recorded for samples of robusta coffee collected in Step I of the processing process and originating from Dschang $(4.8 \mu \mathrm{g} / \mathrm{kg})$ and Bafia $(4.7 \mu \mathrm{g} / \mathrm{kg})$.

The influence of the type of coffee on the mean OTA content of the different samples coffee analyzed in the present study was also assessed. Figure 5 shows that the mean OTA content of robusta coffee is higher than that of arabica coffee. This result means that robusta coffee could be a good substrate for the growth of OTA-producing moulds. This difference in OTA content may arise from the diversity and the load of OTA-producing fungi between the two types of coffee. In a study conducted by Bessaire et al. [37], independent of the geographic origin, storage times, and postharvest processes, robusta coffee was highly contaminated by OTA and other mycotoxins opposite to arabica coffee. A high contamination level of OTA in robusta coffee $(1-27 \mu \mathrm{g} / \mathrm{kg})$ compared to arabica coffee $(0.6$ to $5.5 \mu \mathrm{g} / \mathrm{kg})$ was also noticed by Noonim et al. [38]. The authors highlighted that strains with the greatest OTA-producing potential were $A$. westerdijkiae for arabica coffee and A. carbonarius for robusta coffee. The contamination levels of coffee with these fungal strains were used by Noonim et al. [38] to explain the difference in OTA content of the two types of coffee.

The influence of the treatment applied to coffee on its OTA contents was assessed. Generally, arabica coffee 


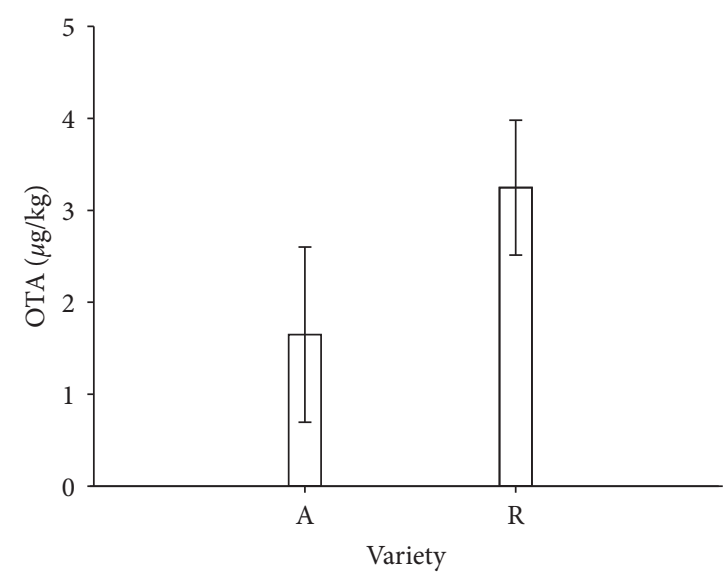

Figure 5: Mean OTA content of the two varieties of coffee sampled (R: robusta; A: arabica) in four Cameroonian cities.

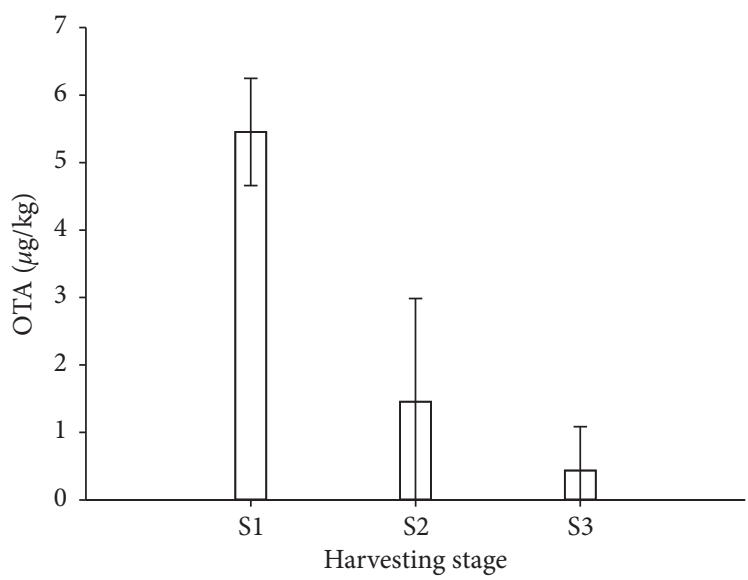

FIGURE 6: Mean OTA content of coffee samples collected at different processing steps. S1 = I (dry cherries); S2 = II (dry husk); S3 = III (green coffee beans).

submitted treatment through a wet route (Figure 1). In that wet route, the unit operation of pulping led to a decrease of OTA content. The level of decrease is different according to the fact that there is a fermentation or not during the pulping. The most important decrease of OTA content obtained in this study through the mechanic process of pulping could be explained by the elimination of an external layer of coffee which is rich in toxins, whereas the fermentative route which is most wet and long in terms of time could favour the penetration (by diffusion) of the toxin into the husk. The hulling removes the toxin through a loss of a new external layer of the coffee bean. However, during the treatment of coffee through the dry route, the increase of OTA content can be explained by a synthesis of OTA by contaminant mould strains [39].

The influence of the sampling step on the OTA content of coffee samples was analyzed in this study and the results are shown in Figure 6. As observed on that figure, the samples collected at Step III (green coffee beans) were the least contaminated one followed with samples collected at Step II (Dry parchment) and finally the sample collected at Step I (Dry cherries) which showed the highest OTA content. Nganou et al. [23] also reported that the level of OTA collected at different steps of coffee processing decrease as its processing level progresses. The decrease of the OTA content when the dry cherries of coffee are processed to obtain the green coffee beans could be due to the fact that the coffee pulp is a good substrate for the growth of OTA-producing moulds. Its removing will reduce the proliferation of these OTA-producing moulds and thus leads to decrease the content of OTA. The decrease of OTA content of coffee through the elimination of their external membrane which OTA-producing moulds was notified by Frank [40] and Suarez-Quiroz et al. [41, 42]. Moreover, the reduction of superficial contamination through the hulling process could also explain the decrease of OTA content of coffee samples obtained in the present study. Similar result was noticed by Nganou [9].

\section{Conclusion}

In summary, the PCR-DGGE technic used in this study enabled a rapid detection of the fungal population of coffee samples collected in three Cameroonian regions. The PCRDGGE technic was successfully used as a traceability tool to determine the origin of the different samples of coffee. 
Mould profiles specific to each of the sampling city involved in this study were identified. The assessment of OTA content of green coffee showed that none of them contained a level higher than the maximum tolerable limit of OTA in food intended for human consumption. The strains $A$. niger, A. carbonarius, and A. ochraceus identified on coffee samples could be responsible for their OTA contamination. The OTA content of coffee samples was influenced by many parameters among which the sampling period and the sampling step during coffee processing were identified as the significant ones.

\section{Data Availability}

The data used in this study are available from the corresponding author upon request.

\section{Conflicts of Interest}

The authors declare no conflicts of interest.

\section{Acknowledgments}

This work was supported by Bioprocessing laboratory of IUT of Ngaoundéré who relented no effort for the realization of this work.

\section{References}

[1] Y. Hamdouche, "Discrimination des procédés de transformation post-récolte du cacao et du café par analyse globale de l'écologie microbienne," Ph.D. thesis, University of Montpellier II, Montpellier, France, 2015.

[2] ICO (International Coffee Organization), Annual Review 2012/2013, London, UK, 2014, http://www.ico.org/news/ annual_review.asp.

[3] M. Barel, Qualité du Cacao. L'impact du Traitement PostRécolte, Edition Quae, Versailles, France, 2013.

[4] R. Saltini, R. Akkerman, and S. Frosch, "Optimizing chocolate production through traceability: a review of the influence of farming practices on cocoa bean quality," Food Control, vol. 29 , no. 1, pp. 167-187, 2013.

[5] I. Perraud-Gaime, "Cultures mixtes en milieu solide de bactéries lactiques et de champignons filamenteux pour la conservation et la décaféination de la pulpe de café," Université de Montpellier II, Montpellier, France, Thèse de Doctorat, 1996.

[6] P. A. Hickcs, "Postharvest processing and quality assurance for specialty/organic coffee products," in The First Asian Regional Round-Table on Sustainable, Organic and Specialty Coffee Production, Processing and Marketing, C. Mai, Thailand, K. Chapman, and S. Subhadra-Bandhu, Eds., Royal Project Foundation Chiang Mai, Thailand, 2001.

[7] R. F. Schwan and A. E. Wheals, "The microbiology of cocoa fermentation and its role in chocolate quality," Critical Reviews in Food Science and Nutrition, vol. 44, no. 4, pp. 205$221,2004$.

[8] A. F. El Sheikha and N. D. Nganou, "Molecular characterization of ochratoxigenic fungal flora as an innovative tool to certify coffee origin," Molecular Techniques in Food Biology: Safety, Biotechnology, Authenticity and Traceability, pp. 47-48, John Wiley \& Sons, Hoboken, NJ, USA, 2018.
[9] N. D. Nganou, "Development of molecular tools for the identification of ochratoxinogenic fungal flora: application to the traceability of Cameroonian coffee," Ph.D. thesis, University of Ngaoundéré, Ngaoundéré, Cameroon, 2012.

[10] T. O. Larsen, A. Svendsen, and J. Smedsgaard, "Biochemical characterization of ochratoxin A-producing strains of the genus Penicillium," Applied and Environmental Microbiology, vol. 67 , no. 8, pp. 3630-3635, 2001.

[11] G. Castella, T. Ostenfeld Larsen, J. Cabanes et al., "Molecular characterization of ochratoxin A producing strains of the genus Penicillium," Systematic and Applied Microbiology, vol. 25, no. 1, pp. 74-83, 2002.

[12] D. M. Vilela, G. V. d. M. Pereira, C. F. Silva, L. R. Batista, and R. F. Schwan, "Molecular ecology and polyphasic characterization of the microbiota associated with semi-dry processed coffee (Coffea arabica L.)," Food Microbiology, vol. 27, no. 8 , pp. $1128-1135,2010$.

[13] D. Duris, J. K. Mburu, N. Durand, R. Clarke, J. M. Frank, and B. Guyot, "Ochratoxin A contamination of coffee batches from Kenya in relation to cultivation methods and postharvest processing treatments," Food Additives \& Contaminants: Part A, vol. 27, no. 6, pp. 836-841, 2010.

[14] T. Kuiper-Goodman, "Risk assessment of ochratoxin A: an update," Food Additives and Contaminants, vol. 13, pp. 535-557, 1996.

[15] D. Höhler, "Ochratoxin A in lebens- und futtermitteln: vorkommen, gesetzliche regelung und wirkungsmechanismen," European Journal of Nutrition, vol. 37, no. 1, pp. 2-12, 1998.

[16] A. Pfohl-Leszkowicz, T. Petkova-Bocharova, I. N. Chernozemsky, and M. Castegnaro, "Balkan endemic nephropathy and associated urinary tract tumours: a review on aetiological causes and the potential role of mycotoxins," Food Additives and Contaminants, vol. 19, no. 3, pp. 282-302, 2002.

[17] L. Abrunhosa, H. Morales, C. Soares et al., "A review of mycotoxins in food and feed products in Portugal and estimation of probable daily intakes," Critical Reviews in Food Science and Nutrition, vol. 56, no. 2, pp. 249-265, 2016.

[18] A. Pfohl-Leszkowicz and R. A. Manderville, "Ochratoxin A: an overview on toxicity and carcinogenicity in animals and humans," Molecular Nutrition \& Food Research, vol. 51, no. 1, pp. 61-99, 2007.

[19] EC (European Commission), "Commission regulation (EC) No. 1881/2006 of 19 december 2006 setting maximum levels for certain contaminants in foodstuffs," Official Journal of European Union, vol. L364, pp. 5-24, 2006.

[20] FAO/WHO, "Fifty-sixth meeting: evaluation of certain mycotoxins that contaminate food," WHO, Geneva, Switzerland, 2001.

[21] M. L. Martins, H. M. Martins, and A. Gimeno, "Incidence of microflora and of ochratoxin A in green coffee beans (Coffea arabica)," Food Additives \& Contaminants, vol. 20, no. 12, pp. 1127-1131, 2003.

[22] R. Laforgue, L. Guérin, J. J. Pernelle, C. Monnet, J. Dupont, and M. Bouix, "Evaluation of PCR-DGGE methodology to monitor fungal communities on grapes," Journal of Applied Microbiology, vol. 107, no. 4, pp. 1208-1218, 2009.

[23] N. Nganou, N. Durand, N. L. Tatsadjieu, I. Métayer, D. Montet, and C. M. F. Mbofung, "Fungal flora and ochratoxin A associated with coffee in Cameroon," British Microbiology Research Journal, vol. 4, no. 1, pp. 1-17, 2014.

[24] A. F. El Sheikha, "Determination of geographical origin of Shea tree and Physalis fruits by using the genetic fingerprints of the microbial community by PCR/DGGE. Analysis of 
biological properties of some fruit extracts," Ph.D. thesis, University of Montpellier II, Montpellier, France, 2010.

[25] A. F. El Sheikha, G. Piombo, T. Goli, and D. Montet, "Main composition of physalis (Physalis pubescens L.) fruit juice from Egypt," Fruits, vol. 65, no. 4, pp. 255-265, 2010.

[26] P. Möhlenhoff, L. Müller, A. A. Gorbushina, and K. Petersen, "Molecular approach to the characterisation of fungal communities: methods for DNA extraction, PCR amplification and DGGE analysis of painted art objects," FEMS Microbiology Letters, vol. 195, no. 2, pp. 169-173, 2001.

[27] P. D. Khot, D. L. Ko, and D. N. Fredricks, "Sequencing and analysis of fungal rRNA operons for development of broadrange fungal PCR assays," Applied and Environmental Microbiology, vol. 75, no. 6, pp. 1559-1565, 2009.

[28] S. Altschul, T. L. Madden, A. A. Schäffer et al., "Gapped BLAST and PSI-BLAST: a new generation of protein database search programs," Nucleic Acids Research, vol. 25, no. 17, pp. 3389-3402, 1997.

[29] E. Stackebrandt and B. M. Goebel, "Taxonomic note: a place for DNA-DNA reassociation and $16 \mathrm{~S}$ rRNA sequence analysis in the present species definition in bacteriology," International Journal of Systematic and Evolutionary Microbiology, vol. 44, no. 4, pp. 846-849, 1994.

[30] T. Palys, L. K. Nakamura, and F. M. Cohan, "Discovery and classification of ecological diversity in the bacterial world: the role of DNA sequence data," International Journal of Systematic Bacteriology, vol. 47, no. 4, pp. 1145-1156, 1997.

[31] E. J. Van Hannen, W. Mooij, M. P. Van Agterveld, H. J. Gons, and H. J. Laanbroek, "Detritus-dependent development of the microbial community in an experimental system: qualitative analysis by denaturing gradient gel electrophoresis," Applied and Environmental Microbiology, vol. 65, no. 6, pp. 24782484, 1999.

[32] G. Muyzer, A. Teske, C. O. Wirsen, and H. W. Jannasch, "Phylogenetic relationships of Thiomicrospira species and their identification in deep-sea hydrothermal vent samples by denaturing gradient gel electrophoresis of $16 \mathrm{~S}$ rDNA fragments," Archives of Microbiology, vol. 164, no. 3, pp. 165-172, 1995.

[33] G. A. Kowalchuk, J. R. Stephen, W. de Boer, J. I. Prosser, T. M. Embley, and J. W. Woldendorp, "Analysis of ammoniaoxidizing bacteria of the beta subdivision of the class Proteobacteria in coastal sand dunes by denaturing gradient gel electrophoresis and sequencing of PCR-amplified 16S ribosomal DNA fragments," Applied and Environmental Microbiology, vol. 63, no. 4, pp. 1489-1497, 1997.

[34] M. Heyndrickx, L. Vauterin, P. Vandamme, K. Kersters, and P. De Vos, "Applicability of combined amplified ribosomal DNA restriction analysis (ARDRA) patterns in bacterial phylogeny and taxonomy," Journal of Microbiological Methods, vol. 26, no. 3, pp. 247-259, 1996.

[35] M. Nakajima, H. Tsubouchi, M. Miyabe, and Y. Ueno, "Survey of aflatoxin B1 and ochratoxin A in commercial green coffee beans by high-performance liquid chromatography linked with immunoaffinity chromatography," Food and Agricultural Immunology, vol. 9, no. 2, pp. 77-83, 1997.

[36] O. Castellanos-Onorio, O. Gonzalez-Rios, B. Guyot et al., "Effect of two different roasting techniques on the Ochratoxin A (OTA) reduction in coffee beans (Coffea arabica)," Food Control, vol. 22, no. 8, pp. 1184-1188, 2011.

[37] T. Bessaire, I. Perrin, A. Tarres, A. Bebius, F. Reding, and V. Theurillat, "Mycotoxins in green coffee: occurrence and risk assessment," Food Control, vol. 96, pp. 59-67, 2019.
[38] P. Noonim, W. Mahakarnchanakul, J. Varga, J. C. Frisvad, and R. A. Samson, "Two novel species of Aspergillus section Nigri from Thai coffee beans," International Journal of Systematic and Evolutionary Microbiology, vol. 58, no. 7, pp. 1727-1734, 2008.

[39] M. Suárez-Quiroz, O. Gonzalez-Rios, M. Barel, B. Guyot, S. Schorr-Galindo, and J.-P. Guiraud, "Effect of the postharvest processing procedure on OTA occurrence in artificially contaminated coffee," International Journal of Food Microbiology, vol. 103, no. 3, pp. 339-345, 2005.

[40] J. M. Frank, "On the activity of fungi in coffee in relation to ochratoxin A production," in Proceedings of the 19th ASIC Coffee Conference, Trieste, Italy, May 2001.

[41] M. L. Suárez-Quiroz, O. González-Rios, M. Barel, B. Guyot, S. Schorr-Galindo, and J. P. Guiraud, "Effect of chemical and environmental factors on Aspergillus ochraceus growth and toxigenesis in green coffee," Food Microbiology, vol. 21, no. 6, pp. 629-634, 2004.

[42] M. Suárez-Quiroz, O. Gonzalez-Rios, M. Barel, B. Guyot, S. Schorr-Galindo, and J.-P. Guiraud, "Study of ochratoxin A-producing strains in coffee processing," International Journal of Food Science and Technology, vol. 39, no. 5, pp. 501-507, 2004. 